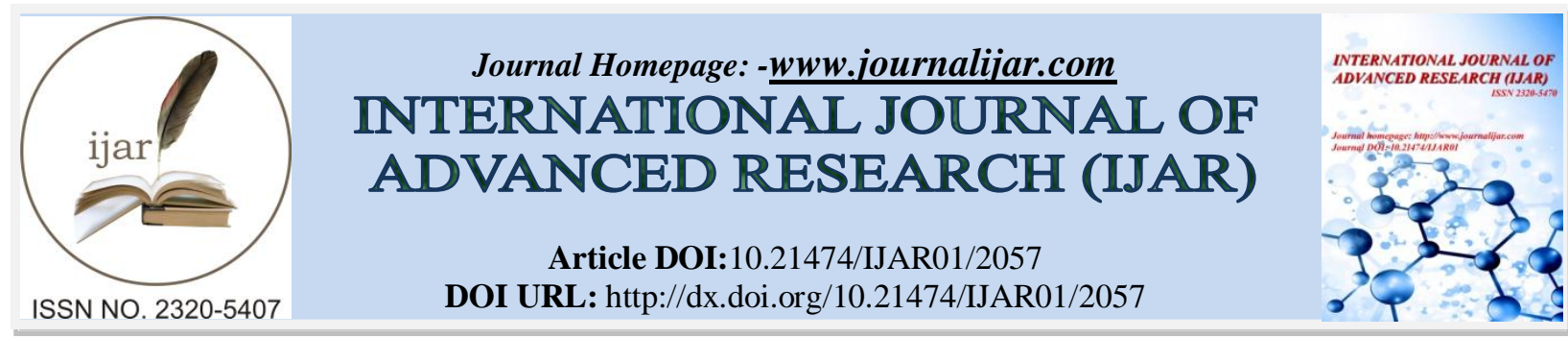

RESEARCH ARTICLE

\title{
CAPABILITY BUILDING USING COMPETENCY DEVELOPMENT FRAMEWORK IN A RECRUITING FIRM.
}

Vatsala Saxena ${ }^{1}$ and Dr. Ravinder Kaur ${ }^{2}$.

1. Student, SIMS, Symbiosis International University, Pune.

2. Faculty, SIMS, Symbiosis International University, Pune.

\section{Manuscript Info}

Manuscript History

Received: 23 September 2016

Final Accepted: 25 October 2016

Published: November 2016

Key words:-

Competency, Capability Building,

Recruitment, Framework.

\section{Abstract}

In today's tempestuousbusiness environment with stiff competition and emerging trends, every organization strives to gain competitive advantage, by recruiting the right people at the right time. With this fact in mind, the researcher has focused on the study conducted in a recruitment firm to understand the prevalence of competency development frameworks to enhance capability building within the firm. The urge of acquiring the best talent, has prompted organizations to outsource their recruitment function, giving rise to the recruitment industry which provides the best solutions at the right time and right cost. As stated in The People Matters this industry is growing by 21 per cent each year, leading to an exponential increase in the competition. Thus, acquiring the best fit for the recruitment firms is essential. The concept of acquire, retain and develop is as prevalent in the recruitment industry as it is in any other sector/line of business which demands to have the right HR policies in place. While these firms recruit for their clients, the competition within the recruitment industry compels these firms to ideate and innovate to maintain the competitive edge. The paper also recommends a few techniques to improve the existing competency assessment and development practices. The recommendations have been put forth with an aim to help improvise on the existing processes of the recruitment firm.

Copy Right, IJAR, 2016,. All rights reserved.

\section{Introduction: -}

The recruitment industry as quoted in info.shine.com is growing by 21 per cent each year, constituting the largest segment in terms the number of players and the size of the market. While it drives numerous changes in the industry of HR within India, the sheer size of this industry with 20,000 players as stated in People Matters Online, poses a large competition to acquire the best talent in every organization. Thus, giving rise to a war of talent within the recruitment industry. The recruitment firms have started hiring the best talent for themselves helping them gain a competitive edge in this segment. There are many challenges posed by the new market environment building in, thus they need to expand their basket of competent capabilities to remain in the competition. 
One such recruitment firm a global market leader in the recruitment industry provides tailor-made solutions to their clientele. With its presence in nearly 30 countries, it has an employee strength of 1,000. A study was conducted within this organization to understand the various competency assessment and development techniques to help acquire and retain the right fit. The capability building taken into consideration for the study was more to do with people than the organization itself. The two areas identified were competencies required to perform the job and the competency development framework in place to help assess those competencies. This firm has its presence in the major cities of India, with a varied workforce composition.

\section{Objectives: -}

1. To identify the competencies possessed by the employees of a specific business vertical

2. To classify the competencies obtained using the available competency frameworks

3. Propose capability building techniques to enhance the existing assessment and development techniques

\section{Methodology: -}

The researcher has conducted an exploratory research utilizing both primary and secondary data. Primary data was obtained by interviewing the employees and HR managers of the firm. Secondary data was provided in the form of company policy book and handbook including the current practices in the firm. Stratified sampling has been utilized to classify the employees into small groups based on their locations. A pilot study was conducted to gather information on employee job responsibilities and areas of expertise at Level - Six. Sample size considered was 50 with the group size of 10, the grouping criterion was location. Data was collected using a questionnaire which comprised of multiple choice and open ended questions. The data obtained was analyzed using Microsoft Excel.

\section{Discussion: -}

Per Garavan\& McGuire (2001) competency to be a set of attributes that an employee utilizes to perform the assigned tasks. The best way to select and develop high performers is by creating a suitable competency development framework as stated by Sandberg (2000). The organization studied uses competency framework developed in-house by experts which covers various competencies divided in different levels namely: Basic, Intermediate, Proficient, Advanced, Expert. This framework is implemented in the hiring process which helps the recruiters align these employees under the above-mentioned categories. Such a classification not only helps the organization find the right fit for the right job, but also helps them maintain an inventory of competencies available within the organization. As brought out by Boon (2000). The functions of competencies can be defined under three perspectives: competencies as individual characteristics; competencies as organization and competencies as a tool of communication between the labor market \& education. This paper encompasses only the first two of the three perspectives mentioned.

\section{Competencies as a function of Individual Characteristics:-}

These are defined as the competencies which are related to the characteristics of an individual. The central view is to assess and emphasize the trainability of a competency thereby predicting the possible contributions of workplace learning activities to the development of competencies. This is supported by other studies conducted by Eraut (1994), Fletcher (1992). These were also known as worker related competencies as per Garavan \& McGuire (2001). The recruitment firm studied follows a step by step process to identify the competencies through an interview method. This organization utilizes various techniques to identify worker related competencies from the pre-defined set encompassed in its competency development framework. 
Note: The below mentioned table is utilized both during the recruitment process and 6 months' post selection into the organization

Table 1: - Methods utilized by the organization to identify competencies of an individual.

\begin{tabular}{|c|c|c|}
\hline Method & Process & Effectiveness \\
\hline $\begin{array}{c}\text { Direct } \\
\text { Observation }\end{array}$ & $\begin{array}{l}\text { - The employees are requested to perform } \\
\text { certain tasks } \\
\text { - Observers take note of the tasks being } \\
\text { performed which forms the basis of } \\
\text { competencies }\end{array}$ & $\begin{array}{l}\text { - Comparatively cheap to implement \& } \\
\text { less time consuming } \\
\text { - Gives a clear picture through the } \\
\text { noticeable actions } \\
\text { - Ineffective for mental assessment } \\
\text { - Subjective in nature }\end{array}$ \\
\hline $\begin{array}{l}\text { Critical Incident } \\
\text { Method }\end{array}$ & $\begin{array}{l}\text { - Involves defining the differences between an } \\
\text { average performer and a high performer } \\
\text { - Employees are requested to describe critical } \\
\text { job incidents } \\
\text { - The same process is repeated multiple times } \\
\text { - Expected outcomes involve the behavior } \\
\text { displayed and outcome }\end{array}$ & $\begin{array}{l}\text { - Capability to capture unusual behavior } \\
\text { - Would require an extensive data } \\
\text { collection process } \\
\text { - Requires thorough knowledge of the } \\
\text { position } \\
\text { - Ability to identify the type of behavior } \\
\text { exhibited }\end{array}$ \\
\hline
\end{tabular}

Competencies as characteristics of the organization: Competitiveness of any organization is determined by the core competencies it possesses as mentioned in the research by Prahalad \& Hamel (1990). These competencies are always firm specific and should be difficult to imitate as stated by Cappelli \& Singh (1992) in their research. The recruitment firm utilizes the following to identify what is also known as work related competencies as per Training Standards Agency (2000)

Note: The below mentioned table is utilized both during the recruitment process and 6 months' post selection into the organization

Table 2: - Methods utilized by the organization to identify job specific competencies.

\begin{tabular}{|c|c|c|}
\hline Method & Process & Effectiveness \\
\hline Expert Panel & $\begin{array}{l}\text { - Panel of senior leaders \& in-house experts } \\
\text { - The panel observes the employees } \\
\text { performing a series of tasks, thus } \\
\text { identifying a list of competencies which are } \\
\text { relevant to the job } \\
\text { - Identify the competencies that require } \\
\text { priority development and activities to be } \\
\text { performed/assigned }\end{array}$ & $\begin{array}{l}\text { - Gives credibility within } \\
\text { organization but may not be the } \\
\text { benchmark within the industry } \\
\text { - Deciding on who should be a } \\
\text { part of the panel for the process } \\
\text { - Suitable for large organizations } \\
\text { - All competencies may not be } \\
\text { covered. }\end{array}$ \\
\hline $\begin{array}{c}\text { Job Competency } \\
\text { Assessment Method }\end{array}$ & $\begin{array}{l}\text { - A team is constituted to identify the } \\
\text { Knowledge and skills required } \\
\text { - Interviews are conducted to identify the } \\
\text { qualities of high performers } \\
\text { - Data obtained is used to modify the } \\
\text { competency model }\end{array}$ & $\begin{array}{l}\text { - Helps identify the job } \\
\text { requirements for individual jobs } \\
\text { - Overlooks personal attributes } \\
\text { - Time-consuming process }\end{array}$ \\
\hline
\end{tabular}

The organization classifies the list of competencies obtained by using table 1 and 2 into three categories. These are: Price of Admission, Competitive Edge and Differentiator. This competency development framework is used while hiring candidates for their organization. There is no competency model being utilized in India by this firm to assess and develop the competencies and right fit for the job later than 6 months of joining. At the middle and senior level, the employee competencies are assessed and development using a competency model which has been stated to be more of a Psychometric assessment.

A series of interviews were conducted to understand how aware are the employees with the competency development framework/model in practice. They were interviewed to collect information on job profile, types of competencies and non-negotiable skills required to perform their daily tasks. 
a. Job Profile: The employees were aware of the job description before they were hired/promoted. The job profile provided by the organization clearly states the tasks that need to be performed and skillsets required by the candidate.

b. Core Competencies: As informed by the internal HR the employees were informed of the competencies required to perform the tasks via the job description. The interview results were collated around the existing competency framework.

Table 3: -Work related competencies derived from employee responses.

\begin{tabular}{|c|c|c|}
\hline Delivery Related & Interpersonal & Strategic \\
\hline Analytical Thinking & Client Focus & Developing Talent \\
\hline Achievement Focus & Diplomatic Sensitivity & Organizational Alignment \\
\hline Drafting Skills & Influencing & Strategic Networking \\
\hline Flexibility & Negotiating & Strategic Thinking \\
\hline Managing Resources & Organizational Knowledge & \\
\hline Team \& Team Leadership & & \\
\hline
\end{tabular}

The researcher has utilized the OECD Competency Framework to classify core competencies such that it can be utilized to assess and develop competencies of employees at the level six. This model can be utilized in tandem with the available competency development framework for the middle and senior level employees.

Additionally, the interviewees were questioned on the non-negotiable skills required to perform the tasks at work. To illustrate the findings, 10 responses have been displayed below.

Table 4:-Non-negotiable skills required to perform the tasks.

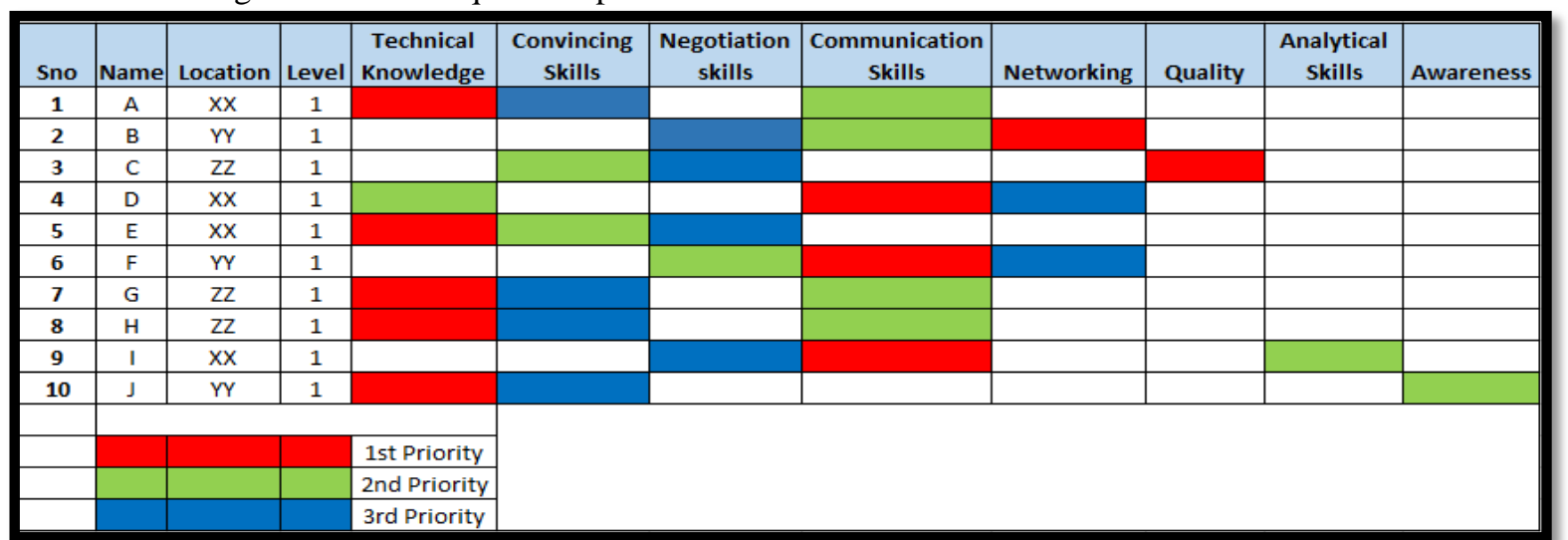

The top fournon-negotiable skills were: technical knowledge, communication skills, convincing skills, negotiations skills. The core competencies and non-negotiable skills are defined based on the nature of the job (functionspecific). The nature of the job is defined by the business of the organization. The employees were provided eight parameters to assess the nature of the job for level six. The illustration of the results obtained have been shown below using 10 responses.

Table 5: -Nature of the Job at Level -6 .

\begin{tabular}{|c|c|c|c|c|c|c|c|c|c|c|c|}
\hline SNO & NAME & LOCATION & LEVEL & $\begin{array}{c}\text { Analysis of } \\
\text { Data }\end{array}$ & Competitiveness & $\begin{array}{c}\text { Customer } \\
\text { Orientation }\end{array}$ & $\begin{array}{c}\text { Frequent } \\
\text { Changes }\end{array}$ & $\begin{array}{c}\text { Frequent Interaction } \\
\text { with others }\end{array}$ & $\begin{array}{c}\text { Organized } \\
\text { Workplace }\end{array}$ & Urgency & Versatility \\
\hline 1 & $\mathrm{~A}$ & $\mathrm{XX}$ & 1 & & & & & & & & \\
\hline 2 & $\mathrm{~B}$ & $\mathrm{YY}$ & 1 & & & & & & & \\
\hline 3 & $\mathrm{C}$ & $\mathrm{ZZ}$ & 1 & & & & & & & \\
\hline 4 & $\mathrm{D}$ & $\mathrm{XX}$ & 1 & & & & & & & \\
\hline 5 & $\mathrm{E}$ & $\mathrm{XX}$ & 1 & & & & & & & \\
\hline 6 & $\mathrm{~F}$ & $\mathrm{YY}$ & 1 & & & & & & & \\
\hline 7 & $\mathrm{G}$ & $\mathrm{ZZ}$ & 1 & & & & & & & \\
\hline 8 & $\mathrm{H}$ & $\mathrm{ZZ}$ & 1 & & & & & & & \\
\hline 9 & $\mathrm{I}$ & $\mathrm{XX}$ & 1 & & & & & & & \\
\hline 10 & $\mathrm{~J}$ & $\mathrm{YY}$ & 1 & & & & & & & & \\
\hline \hline
\end{tabular}


Table 5 illustrates that customer orientation is of utmost importance in level six which is tandem with what the organization stands for. As per the findings, to remain customer oriented, the work and worker related competencies need to be identified in tandem with the nature of the job and organization.

\section{Recommendations: -}

The recommendations provided to the recruitment firm were in alignment to the finding and analysis. At the junior level, the organization does not have any formal competency model to assess performance and develop competencies on a continuous basis. It was suggested that conducting personality assessment tests on a regular basis in tandem with the OECD Competency Framework can help the organization assess the right fit for the job. The suggested personality tests along with their comparative analysis are as follows:

Table 6:-Comparative analysis of the suggested personality tests.

\begin{tabular}{|c|c|c|}
\hline Parameters & Meyers-Briggs Personality Test & Birkman Method \\
\hline \multirow[t]{2}{*}{ Level of Application } & - Junior Level & - $\quad$ Junior Level \\
\hline & - $\quad$ Campus Recruitment Drives & - $\quad$ Campus Recruitment Drives \\
\hline \multirow[t]{5}{*}{ Areas of Application } & - $\quad$ Leadership Development & - $\quad$ Leadership Development \\
\hline & - $\quad$ Team Building & - $\quad$ Career Exploration \\
\hline & - $\quad$ Career Selection & - $\quad$ Team Building \\
\hline & - $\quad$ Screening \& Interviewing employees & - $\quad$ Talent Selection \\
\hline & - $\quad$ Personal Development & - $\quad$ Sales \& Negotiation \\
\hline \multirow[t]{6}{*}{ Measures of the method } & - $\quad$ MBTI Type at work & $\begin{array}{l}\text { - Interests: Activities that } \\
\text { motivate you in your personal } \\
\text { and professional life }\end{array}$ \\
\hline & - $\quad$ Personality \& Careers & $\begin{array}{llr}\text { Usual Behaviour: } & \text { The } \\
\text { productive and effective } \\
\text { behavioural style } \\
\text { relationships and tasks }\end{array}$ \\
\hline & - Type use in profession & $\begin{array}{l}\text { - Underlying Needs: How you } \\
\text { expect to be treated by others } \\
\text { and how you need to be as per } \\
\text { your surroundings }\end{array}$ \\
\hline & - Cognitive Learning Styles & $\begin{array}{l}\text { - Stress Behaviour: The } \\
\text { unproductive and ineffective } \\
\text { behavioural styles when } \\
\text { individual needs are unmet }\end{array}$ \\
\hline & - $\quad$ Psychological types \& Learning & - $\quad$ Career Data: 22 Job Families \\
\hline & - $\quad$ Type in Personal Growth & and $200+$ Unique job titles \\
\hline \multirow[t]{5}{*}{ Features } & \multirow[t]{5}{*}{ - $\quad$ Tailor - made } & - Online assessment \\
\hline & & $\begin{array}{l}298 \text { questions }(48 \text { multiple- } \\
\text { choice questions, } 250 \text { true-false } \\
\text { type) }\end{array}$ \\
\hline & & - $\quad 30$ Minutes (Average time) \\
\hline & & $\begin{array}{lll}\text { - } & \begin{array}{l}\text { Results available } \\
\text { completion }\end{array} & \\
\end{array}$ \\
\hline & & $\begin{array}{l}\text { - } \begin{array}{l}\text { Questionnaire available in } 20 \\
\text { languages }\end{array} \\
\end{array}$ \\
\hline \multirow[t]{4}{*}{ Types of Reports Generated } & - $\quad$ Best type Fit & - $\quad$ Career Management Report \\
\hline & \multirow[t]{3}{*}{ - $\quad$ Personality Assessment } & - Difference/Issues to Look for \\
\hline & & - $\quad$ Interpersonal Needs Summary \\
\hline & & - $\quad$ Strengths and Needs graph \\
\hline
\end{tabular}

The researcher also recommended to implement an Individual Development Plan famously known as an IDP to understand the needs of an employee and align them with the organization goals. This will help the firm plan for its 
future talent requirements and utilize the available talent in-house for senior positions. Also, the firm must conduct workshops for employees to help them understand the utility and importance of the competency development framework/personality assessments in their professional career. This can be done by delivering training and development in a competency context; have employees prepare an individual development plan to assess their strengths, weakness and training requirements to improve the same; provide competency feedback to enhance the performance of the employees at Level Six. The analysis of how would the organization benefit from an individual development plan is as follows:

Table 7:- Analysis of an Individual Development Plan.

\begin{tabular}{|c|c|}
\hline \multirow[t]{3}{*}{ Level of Application } & - Junior Level \\
\hline & - $\quad$ Middle Level \\
\hline & - $\quad$ Senior Level \\
\hline \multirow[t]{4}{*}{ Features } & - $\quad$ SWOT Analysis \\
\hline & - $\quad$ Setting goals \\
\hline & - $\quad$ Personal Objectives \\
\hline & - Job Analysis \\
\hline \multirow[t]{5}{*}{ Measures of the method } & - $\quad$ Strengths/Weaknesses \\
\hline & - $\quad$ Gap Analysis \\
\hline & - $\quad$ Long term \& Short term goals \\
\hline & $\begin{array}{l}\text { - In-depth analysis of the job from employee } \\
\text { perspective }\end{array}$ \\
\hline & - $\quad$ Short term blocks \\
\hline \multirow[t]{6}{*}{ Procedure to create an IDP } & $\begin{array}{l}\text { - Employee must be provided an SOP to create an } \\
\text { IDP }\end{array}$ \\
\hline & - $\quad$ Train the Manager in reviewing an IDP \\
\hline & - $\quad$ Employee must create his/her IDP \\
\hline & $\begin{array}{l}\text { - Discuss with manager to align the IDP with } \\
\text { business objectives }\end{array}$ \\
\hline & $\begin{array}{l}\text { - Manager should prepare a gap analysis report for } \\
\text { the individual }\end{array}$ \\
\hline & - $\quad$ Finalize the IDP and set a date for review \\
\hline
\end{tabular}

\section{Conclusion: -}

Through this paper, the importance of competency assessment and development at junior level have been discussed. To maintain the competitive edge, the firm must align its human capital with its vision and mission. This can be achieved by understanding the line of business and accordingly preparing the appropriate competency frameworks to identify critical competencies and develop it. It is thereby essential to implement such models/framework from the recruitment phase as per the cost feasibility. Personality assessments, prepared in-house must be continually implemented to enhance employee performance thus delivering the right solutions to their clients. These also involve giving autonomy to the employees in terms of charting their own career path within the organization. Aligning the competency framework with the right kind of training and development practices is the need of the hour. Lastly, measures to test the effectiveness of the system in place gives a quantitative perspective to an employee performance.

\section{Limitations\& scope for further study: -}

The study has majorly focused on the competency development aspect to enhance the effectiveness of the employees. It does not touch upon the learning and development in the context of competencies.

Capability Building through competency development framework can be studied in context of succession planning, high potentials. 


\section{References: -}

1. Alldredge, M. E., \& Nilan, K. J. (2000). 3M's leadership competency model: An internally developed solution. Human resource management, 39(2, 3), 133.

2. Antonacopoulou, E. P., \& FitzGerald, L. (1996). Reframing competency in management development. Human Resource Management Journal, 6(1), 27-48.

3. Athey, T. R., \& Orth, M. S. (1999). Emerging competency methods for the future. Human resource management, 38(3), 215-225.

4. Bergenhenegouwen, G. J. (1996). Competence development-a challenge for HRM professionals: core competences of organizations as guidelines for the development of employees. Journal of European Industrial Training, 20(9), 29-35.

5. Boam, R., \& Sparrow, P. (Eds.). (1992). Designing and achieving competency: a competency-based approach to developing people and organizations. McGraw-Hill Book Company Limited.

6. Richard E. Boyatzis. (1982). The competent manager: A model for effective performance. John Wiley \& Sons.

7. Boyatzis, R. E., Goleman, D., \& Rhee, K. (2000). Clustering competence in emotional intelligence: Insights from the Emotional Competence Inventory (ECI). Handbook of emotional intelligence, 343-362.

8. Brown, R. B. (1993). Meta-competence: A recipe for reframing the competence debate. Personnel Review, 22(6), 25-36.

9. Buckman, R. H. (2004). Building a knowledge-driven organization. New York, NY: McGraw-Hill.

10. Burgoyne, J. (1988). Competency based approaches to management development. Centre for the study of management learning, Lancaster.

11. Campbell, A., \&Luchs, K. S. (Eds.). (1997). Core competency-based strategy. Cengage Learning Business Press.

12. Cappelli, P., \& Singh, H. (1992). Integrating strategic human resources and strategic management. Research frontiers in industrial relations and human resources, 165, 192.

13. Cardy, R. L., \&Selvarajan, T. T. (2006). Competencies: Alternative frameworks for competitive advantage. Business Horizons, 49(3), 235-245.

14. Cheng, M. I., Dainty, A. R., \& Moore, D. R. (2005). Towards a multidimensional competency-based managerial performance framework: A hybrid approach. Journal of Managerial Psychology, 20(5), 380-396.

15. Heene, A., \& Sanchez, R. (Eds.). (1997). Competence-based strategic management. London: Wiley.

16. Cooper, K. (2000). Effective competency modeling \& reporting: a step-by-step guide for improving individual $\&$ organizational performance. AMACOM Div American Mgmt Assn.

17. Cooper, K. (2000). Effective competency modeling \& reporting: a step-by-step guide for improving individual \& organizational performance. AMACOM Div American Mgmt Assn.

18. Doz, Y., Prahalad, C. K., Hamel, G., Bartlett, C. A., Doz, Y., \&Hedlund, G. (1990). Control, change and flexibility: the dilemma of transnational collaboration.

19. Le Deist, F. D., \&Winterton, J. (2005). What is competence?. Human resource development international, 8(1), 27-46.

20. Dubois, D. D. (1993). Competency-Based Performance Improvement: A Strategy for Organizational Change. HRD Press, Inc., 22 Amherst Road, Amherst, MA 01002.

21. Dulewicz, V., \& Herbert, P. (1992). Personality, competences, leadership style and managerial effectiveness. Henley The Management College.

22. Eraut, M. (1994). Developing professional knowledge and competence. Psychology Press.

23. Eisenhardt, K. M., \& Martin, J. A. (2000). Dynamic capabilities: what are they?. Strategic management journal, 21(10-11), 1105-1121.

24. Eisenhardt, K. M., \& Martin, J. A. (2000). Dynamic capabilities: what are they?. Strategic management journal, 21(10-11), 1105-1121.

25. Winterton, J. (2009). Competence across Europe: highest common factor or lowest common denominator?. Journal of European industrial training,33(8/9), 681-700.

26. Winterton, J. (2009). Competence across Europe: highest common factor or lowest common denominator?. Journal of European industrial training,33(8/9), 681-700.

27. Fletcher, S. (1992). Standards and competence: A practice guide for employers, management and trainers.

28. Le Deist, F. D., \&Winterton, J. (2005). What is competence?. Human resource development international, 8(1), 27-46.

29. Garavan, T. N., \& McGuire, D. (2001). Competencies and workplace learning: some reflections on the rhetoric and the reality. Journal of Workplace learning, 13(4), 144-164. 
30. Granstrand, O., Patel, P., \& Pavitt, K. (1997). Multi-technology corporations: why they have" distributed" rather than" distinctive core" competencies.California management review, 39(4), 8-25.

31. Green, P. (1999). Building robust competencies: Linking human resource systems to organizational strategies. Jossey-Bass Inc Pub.

32. Goh, S. C. (2003). Improving organizational learning capability: lessons from two case studies. The learning organization, 10(4), 216-227.

33. Gould, J. M. (2009). Understanding organizations as learning systems.Strategic learning in a knowledge economy, 119-140.

34. Hao, Y. (2016, July). Innovation Strategies of Mobile Operator's HRM Model in Transition Period of Mobile Internet. In 2016 International Symposium on Computer, Consumer and Control (IS3C) (pp. 57-60). IEEE.

35. Jokinen, T. (2005). Global leadership competencies: a review and discussion. Journal of European Industrial Training, 29(3), 199-216.

36. Kim, L. (1998). Crisis construction and organizational learning: Capability building in catching-up at Hyundai Motor. Organization science, 9(4), 506-521.

37. Le Deist, F. D., \&Winterton, J. (2005). What is competence?. Human resource development international, 8(1), 27-46.

38. Lenburg, C. B. (1999). The framework, concepts and methods of the competency outcomes and performance assessment (COPA) model. Online Journal of Issues in Nursing, 4(2), 1-12.

39. Marcus, S. H., \& Pringle, A. (1995). What new competencies are needed in a changing environment. The Human Resources Professional, 8(3), 19-24.

40. Markides, C. C., \& Williamson, P. J. (1994). Related diversification, core competences and corporate performance. Strategic Management Journal,15(S2), 149-165.

41. Mayer, D., \& Kenney, M. (2004). Economic action does not take place in a vacuum: Understanding Cisco's acquisition and development strategy.Industry and Innovation, 11(4), 299-325.

42. Mulder, M., Weigel, T., \& Collins, K. (2007). The concept of competence in the development of vocational education and training in selected EU member states: a critical analysis. Journal of Vocational Education \& Training, 59(1), 67-88.

43. Murray, P., \&Donegan, K. (2003). Empirical linkages between firm competencies and organisational learning. The Learning Organization, 10(1), 51-62.

44. Pickett, L. (1998). Competencies and managerial effectiveness: Putting competencies to work. Public Personnel Management, 27(1), 103-115.

45. Prahalad, C. K., \& Hamel, G. (2006). The core competence of the corporation. In Strategischeunternehmungsplanung_strategischeunternehmungsführung (pp. 275-292). Springer Berlin Heidelberg.

46. Quinn, R. E. (2003). Becoming a master manager: A competency framework. John Wiley \& Sons Inc.

47. Sandberg, J. (2000). Understanding human competence at work: an interpretative approach. Academy of management journal, 43(1), 9-25.

48. Sanghi, S. (2007). The handbook of competency mapping: understanding, designing and implementing competency models in organizations. SAGE Publications India.

49. Sparrow, P. (1995). Organizational competencies: a valid approach for the future?. International Journal of Selection and Assessment, 3(3), 168-177.

50. Thompson, J. E., Stuart, R., \& Lindsay, P. R. (1996). The competence of top team members: a framework for successful performance. Journal of Managerial Psychology, 11(3), 48-66.

51. Ulrich, D., Brockbank, W., Yeung, A. K., \& Lake, D. G. (1995). Human resource competencies: An empirical assessment. Human resource management, 34(4), 473-495.

52. Ulrich, D., \& Lake, D. (1991). Organizational capability: Creating competitive advantage. The Executive, 5(1), 77-92.

53. Ulrich, D., \& Lake, D. G. (1990). Organizational capability: Competing from the inside out. John Wiley \& Sons.

54. Vazirani, N. (2010). Competencies and competency model-a brief overview of its development and application. SIES Journal of management, 7(1), 121. 